\title{
EFFECT OF LOW-INTENSITY LASER IRRADIATION ON FIELD PERFORMANCE OF MAIZE (ZEA MAYS L.) EMERGENCE, PHENOLOGICAL AND SEED QUALITY CHARACTERISTICS
}

\author{
HASAN, M. ${ }^{1}$ - HANAFIAH, M. M. ${ }^{1,2^{*}}-$ TAHA, Z. A. ${ }^{3}-$ ALHILFY, I. H. H. ${ }^{4}$ \\ ${ }^{I}$ Department of Earth Sciences and Environment, Faculty of Science and Technology, Universiti \\ Kebangsaan Malaysia, 43600 Bangi, Selangor, Malaysia \\ ${ }^{2}$ Centre for Tropical Climate Change System, Institute of Climate Change, Universiti \\ Kebangsaan Malaysia, 43600 Bangi, Selangor, Malaysia \\ ${ }^{3}$ Institute of Laser for Postgraduate Studies, University of Baghdad, Baghdad 00964, Iraq \\ ${ }^{4}$ Department of Field Crop Science, College of Agriculture, University of Baghdad, Baghdad \\ 00964, Iraq \\ ${ }^{*}$ Corresponding author \\ e-mail:mhmarlia@ukm.edu.my; phone: +60-389-215-865
}

(Received $30^{\text {th }}$ Apr 2020; accepted 29 $9^{\text {th }}$ Jul 2020)

\begin{abstract}
Laser application in agriculture has attracted much interest due to the improvement of plant characteristics after laser pre-sowing seed treatment. In this study, Zea mays L. seeds were pre-irradiated by a single exposure to blue laser at different intensities $\left(2\right.$ and $\left.4 \mathrm{~mW} / \mathrm{cm}^{2}\right)$ and different irradiation times of $45,65,85$, and $105 \mathrm{~s}$. The field emergence characteristics (i.e., emergence $\%$, mean emergence time, emergence index, vigor index, growth parameters, and seed quality) of laser-induced Zea mays L. seeds were determined and compared with those of unirradiated seeds. A randomized complete block design (RCBD) was employed with three replications. The growth characteristics of the seeds exposed to laser for 85s showed significant improvements in terms of the seedling length and leaf number. Additionally, there were observable alterations in the seed emergence percentage (91.66\%), emergence index (7.25), and vigor index (520.80) in the seeds irradiated for $85 \mathrm{~s}$ at a laser intensity of $4 \mathrm{~mW} / \mathrm{cm}^{2}$. In seeds irradiated for $85 \mathrm{~s}$, both the oil and starch contents were increased by $6.33 \%$ and $73.11 \%$, respectively. On the other hand, there was an increase in the protein content of maize seeds (18\%) with increased laser intensity. In conclusion, the results of the present study demonstrated that $4 \mathrm{~mW} / \mathrm{cm}^{2}$ of blue laser and the irradiation period of $85 \mathrm{~s}$ enhanced the emergence process of maize plants.
\end{abstract}

Keywords: low power, blue laser, exposure time, seed stimulation, physical priming

\section{Introduction}

Laser radiation has been found application in all spheres of engineering due to its basic characteristics, such as coherence, monochromaticity, polarization, and power density. However, these attributes of laser radiation have also made it applicable in biological and agricultural sectors. Upon exposure to laser radiation, certain changes occur in the physiological state of plants and seeds and such changes can either induce or inhibit the development of such plant or seed based on the type of laser radiation used, as well as its intensity and wavelength (Hasan et al., 2020). There are several light-absorbing molecules in nature which mediates the response of organisms to change in the natural light environment. The changes in the light parameter influence various physiological processes (i.e. intra and inter-cellular differentiation, seed germination and seedling growth, photosynthesis, flowering, etc.) depending on the species and developmental 
stage or studied organ (He et al., 2017). It has been reported earlier that light is an absolute factor that regulates seed germination in numerous plant species (Jala, 2011).

Several previous studies reported the effects of light on the germination and growth of seeds of plants (Hernandez et al., 2010; Aladjadjiyan, 2012; Qiu et al., 2017; Alsalhi et al., 2018). Some plant seeds require light to grow while the germination of some plant seeds can be inhibited in the presence of light (Hernandez and Michtchenko, 2011; Atif et al., 2020). According to Jala (2011), different levels of exposure time to light can have various influences on the germination parameters of different seeds. Furthermore, when low-power laser light is used on seeds, seedlings, and plants, it produces bio-stimulation (Hernandez et al., 2009, 2010, 2015; Perveen et al., 2010; Hernández and Michtchenko, 2011; Aladjadjiyan, 2012; Jia and Duan, 2013; Hasan et al., 2020).

Without a doubt, the $21^{\text {st }}$ century needs to develop technologies to increase the global production of food since one of the main challenges of our time is to feed a growing world population (Foley, 2011; Muhammad-Muaz and Marlia, 2014; Hanafiah et al., 2019) which has been projected to grow by two to three billion of people by the year 2050. This implies that the world population will increase to 9000 million (FAO, 2011), with a simultaneous doubled increase in food cost, the problem of hunger will worsen. At the same time, the need to reduce damage to the environment is considered (Foley, 2011; Aziz et al., 2020a). All these, under the current context and the future climate changes, lead to threatened areas with high temperature (Harun and Hanafiah, 2018; Aziz et al., 2020b) and year forecasts are extremely unfavourable (Field et al., 2012; Fadillah and Marlia, 2016). Therefore, several methods have been introduced to increase crop yield including by laser irradiation.

Bioeffects due to low laser power in seed pre-planting and in seedlings or plants during their development have been confirmed by numerous studies using seeds of various crops (Osman et al., 2009; Aladjadjiyan, 2012; Hoseini et al., 2013; Kouchebagh et al., 2014a; Śliwka, 2014; Srećković et al., 2014). From the introduction of lasers in the '60s (Nasim and Jamil, 2014), its application began in biological systems (Bessis et al., 1962), dabbling to the agricultural sector as a bio-stimulatory element (BE) of plants and seeds with the ruby laser (Wilczek et al., 2005). He-Ne (Helium-Neon), Ar (Argon), Neodymium- YAG (Nd-YAG), carbon dioxide $\left(\mathrm{CO}_{2}\right)$ and diodes (in different wavelengths $-\lambda$ ) have been applied to conjecture the use of laser technology for preseeding treatment or during some of the phenological stages of the crops (Chen et al., 2005; Hernandez, 2009; Hernandez et al., 2010, 2015; Hernández and Michtchenko, 2011; Aladjadjiyan, 2012; Śliwka, 2014). Laser technology has evolved and has been applied in bio-stimulation processes of seeds and plants. He-Ne laser is the most applied laser as BE of seeds and/or plants since its foray into agriculture until today (Aladjadjiyan, 2012; Hernández et al., 2015; Hasan et al., 2020).

In this way, it is interesting to study the optimum laser irradiation parameters to produce favourable bioeffects and when applied in the agricultural sector, could, among other effects, increase the performance of products, stems and seeds, reduce the vegetative period, improve the quality of harvest, produce vigorous plants, improve the photosynthetic evolution of plants, break the seed dormancy, stimulate germination, recover the soil, and protect the environment against toxigenic mold and bacteria (Podleśna et al., 2015).

During the bio-stimulation of plants at various developmental phases of the plant, three kinds of photoreceptors (phytochromes, phototropins, and cryptochromes) have been found to absorb light at different wavelengths of 600-750, 320-500 and 500-630 nm, 
respectively (Bouly et al., 2007; Levskaya et al., 2009). This implies that the seeds, based on their respective characteristics (physical, chemical, optical, thermal, photothermal, genotypic, phenotypic, etc.) will first take in the light energy and transform it into chemical energy for use in their subsequent growth phases (Jamil et al., 2013). As such, the kinetic equilibrium of seed germination processes can be altered by exposure to laser light, thereby increasing the internal energy of the seeds (Ferdosizadeh et al., 2013) and varying the response according to the seed type and cultivar.

Based on the previous studies, the physiological quality of certain crops has been improved using He-Ne $(632.8 \mathrm{~nm})$ and laser diodes $(650,660 \mathrm{~nm})$ bio-stimulation. Among such crops are Zea mays L., Triticum (Joshi et al., 2012; Jamil et al., 2013), Carthamus tinctorius L., Helianthus annuus L., Brassica napus L. (Ashrafijou et al., 2010; Perveen et al., 2010), Medicago sativa, Vicia faba, Lathyrus sativus L. (Qi et al., 2002; Truchliñski et al., 2002; Wilczek, 2005), Raphanus sativus L., Solanum lycopersicum L. (Álvarez et al., 2011; Jia and Duan, 2013), Acacia farnesiana L., Ricinus communis L. (Soliman and Harith, 2009), Balanites aegyptiaca, Celosia argéntea, Beta vulgaris L. (Metwally et al., 2013; Podleśna et al., 2015). Germination is the initial stage of development in the growth of crops. During this stage, the important seed quality parameters that can affect the plant status are the germination rate, seed vigor, and germination uniformity (Mohssen-Nasab et al., 2010). Thus, this study aims to determine the effect of different intensity of blue laser irradiation on maize seeds, in terms of their field emergence parameters, growth, and seed quality.

\section{Materials and Methods}

\section{Study Area}

This research was conducted in the experimental field located at the Faculty of Agriculture, University of Baghdad and Laser Laboratory, Institute of Laser for Postgraduate Studies, University of Baghdad (33 $3^{\circ} 16^{\prime} 26^{\prime \prime} \mathrm{N}, 44^{\circ} 22^{\prime} 39^{\prime \prime}$ E). The experimental site has a hot dry climate in summer season in 2018 , the average temperature was in the range of $17.1^{\circ} \mathrm{C}$ to $31.6^{\circ} \mathrm{C}$, with an annual average rainfall of $284.2 \mathrm{~mm}$ and average humidity of $45 \%$. Soil samples were randomly collected from the field and transferred to the lab to measure the physical-chemical parameters. The soil was slightly alkaline $\mathrm{pH}$ (7.2), salt-free (electrical conductivity $3.8 \mathrm{meq} / 100 \mathrm{~g}$ soil), nitrate and ammonia nitrogen concentrations of $0.0017 \%$ and $0.009 \%$, respectively, very high $\mathrm{P}$ assimilation rate $(43.2 \mathrm{mg} / \mathrm{kg})$, and high $\mathrm{K}(1.6 \mathrm{mg} / \mathrm{L})$. The soil texture was silt $(28.9 \mathrm{~g} / \mathrm{kg})$, clay $(38.5 \mathrm{~g} / \mathrm{kg})$ and sand $(32.6 \mathrm{~g} / \mathrm{kg})$.

\section{Laser Irradiation Experiment}

A blue laser source of $100 \mathrm{~mW}$ power $(410 \mathrm{~nm})$ was used in this study. A $100 \mathrm{~cm}$ distance was maintained between the laser and the seed samples. The seeds were positioned in a steady manner on the side facing the embryo and hanged in the air (supported on one side by a heat dissipater). To ensure that the laser diode operates in a normal mode for a prolonged period, it was placed in a special bed in the modules' ribbed part to provide good cooling. Optics were used in the lasers to ensure the provision of the optimum laser power. Additionally, the irradiation power intensity of the laser was set at 2 and $4 \mathrm{~mW} / \mathrm{cm}^{2}$, the intensity was measured using a power meter. The blue laser was used to irradiate the maize seeds for different exposure times of 45, 65, 85 and $105 \mathrm{~s}$. The 
optimum period for each treatment was monitored using a time controller device. The parts of the device and the positioning of the treated seeds are depicted in Table 1.

Table 1. Experimental conditions used for seed pre-treatment of maize

\begin{tabular}{c|c}
\hline Excremental condition & Details \\
Laser type & Diode laser \\
Wavelength & $410 \mathrm{~nm}$ \\
Power intensity & 2, and $4 \mathrm{~mW} / \mathrm{cm}^{2}$ \\
Laser exposition time & $45,65,85$, and $105 \mathrm{~s}$ \\
Wave emission & Continuous $(\mathrm{CW})$ \\
Beam size & $2 \mathrm{~mm}$ \\
Distance from sample & $100 \mathrm{~cm}$ \\
Cultivar treated & Baghdad 3 \\
\hline
\end{tabular}

\section{Experimental Design}

In summer 2018, a 4x2 factorial experimental design was conducted for blue laser exposure times $\left(\mathrm{T}_{1}=45, \mathrm{~T}_{2}=65, \mathrm{~T}_{3}=85\right.$ and $\left.\mathrm{T}_{4}=105 \mathrm{~s}\right)$ at $410 \mathrm{~nm}$, two intensities $\left(\mathrm{P}_{1}=4\right.$ and $\mathrm{P}_{2}=2 \mathrm{~mW} / \mathrm{cm}^{2}$ ), and a control (without exposure to laser) in a design of complete blocks with three replications. The land was fallow, harrowed and furrowed with machinery. Planting was carried out manually in dry soil at a plant density of 6667 plants/ha, and inter-plant distance of $25 \mathrm{~cm}$. In this study, 600 seeds were pretreated before sowing in the field. The size of the experimental plot was 2 meters wide by 1.5 meters long. Total irradiated seeds were 1600. This study used maize seed variety (Baghdad 3 cultivar) provided by the Office of Agriculture Research, Baghdad. The seed variety was grown during the planting season (spring-summer) in July 2018 in the experimental field. The seeds lot was first standardized with respect to size and colour, followed by seeds dipped into a sodium hypochlorite solution $(1 \% \mathrm{v} / \mathrm{v})$ for sterilization and then rinsed in tap water for several time periods and left to dry by room temperature prior to irradiation. From each treatment group, six seeds were selected and measured for thicknesses using a Vernier instrument. The observed average thickness of the seeds was $3.9 \mathrm{~mm}$.

The fertility of the fields was improved with $520 \mathrm{~kg} / \mathrm{ha}$ of compost $\left(46: 18\right.$ of N: $\left.\mathrm{P}_{2} \mathrm{O}_{5}\right)$ and prior to sowing, the soil was fertilized with $436 \mathrm{~kg} / \mathrm{ha}$ of urea (1/2 before sowing and the rest at the flowering stage). During the growing period, weeding was done manually while insects were controlled chemically using diazinon at the rate of $6 \mathrm{~kg} / \mathrm{ha}$ which was applied at 20 and 35 days after sowing. The crops were harvested manually after 110 days from the date of sowing. The drying of the ears was natural in a ventilated place and in the shade. It was manually de-grained when the moisture content of the grain was around $15 \%$ and the grain was stored at a temperature of $25^{\circ} \mathrm{C}$.

\section{Parameters Measurement}

A daily count of seedling emergence was conducted while the other seedling parameters (emergence \%, emergence index, vigor index) were recorded after the viable seeds have emerged (no new seed emergence observed). The mean emergence time (MET) was calculated using Eq. 1 as follows: 
where $\mathrm{D}=$ number of days that elapsed from the first day of sowing, and $\mathrm{n}=$ the number of emerged seeds on day D.

Emergence index (EI) was calculated according to The Association of Official Seed Analysis (1978) formula in Eq. 2:

$$
\begin{aligned}
\mathrm{EI}= & \text { No. of emerged seeds } / \text { Day of first count }+\ldots \\
& + \text { No. of emerged seeds/Day of final count }
\end{aligned}
$$

Emergence speed was calculated by Eq. 3:

$$
\mathrm{Es}=\sum \mathrm{Ni} / \mathrm{Di}
$$

where, $\mathrm{Ni}=$ number of seeds emerged per day. $\mathrm{Di}=$ Number of days (daily germination).

Seedling vigor index was calculated as below (Eq. 4):

$$
\text { Vigor Index }(\mathrm{VI})=\text { emergence }(\%) \mathrm{x} \text { Seedling length }(\mathrm{cm})
$$

Flowering dates: Dates when $100 \%$ of the plants in a plot attained anthesis and incipient silk extrusion were recorded and expressed as days after planting, as well as stem diameter, and seedling leaves number at $21^{\text {th }}$ days after planting were measured.

Seedling heights at $21^{\text {th }}$ day after planting: This is the measure of a distance from the surface of the soil to the flag leaf-bearing nodes. Fresh weight was determined and dry weight was calculated by drying seedling (at $21^{\text {th }}$ day after planting) in an oven at $75^{\circ} \mathrm{C}$ until the weight remained constant. The top ear was determined from 5 randomly selected plants in a plot and the mean of the measurements was determined and presented as the plant height. The proximate composition of the grain, including protein, starch, and oil were analysed after harvesting based on the method prescribed by AACC (2000).

\section{Statistical Analysis}

The acquired data in this study were analyzed using Genstat ${ }^{\circledR}$ Statistical software version 19. The software was used to analyze the analysis of variance (ANOVA) at a significance level of $p<0.01$; the Fisher's test was used to define the observed levels of significant differences between the means of the datasets. All the measurements were performed in triplicates.

\section{Results}

Table 2 shows the seed emergence percentage and other parameters. Evidently, each laser exposure time and intensity significantly influenced the field emergence percentage. The percentage of emergence was found to be increased over the control, reaching a maximum seed emergence percentage of $91.6 \%$ by seeds irradiated with $4 \mathrm{~mW} / \mathrm{cm}^{2}$ laser intensity for $85 \mathrm{~s}$. A decreased percentage was observed at $65 \mathrm{~s}$ as the lowest seed emergence percentage of 58.6 and $62.5 \%$ was recorded from the seeds irradiated at $65 \mathrm{~s}$ and the un-irradiated control seeds, respectively. The increased percentage of emergence was significantly different $(\mathrm{p}<0.01)$ when compared to the control seeds. 
Table 2. Field emergence and growth components after seed pre-treatment with blue laser

\begin{tabular}{|c|c|c|c|c|c|c|c|c|c|}
\hline Treatments & $\begin{array}{c}\text { emergence } \\
\%\end{array}$ & $\begin{array}{c}\text { emergence } \\
\text { index }\end{array}$ & \begin{tabular}{|c|} 
emergence \\
speed \\
(hour)
\end{tabular} & $\begin{array}{c}\text { mean } \\
\text { emergence } \\
\text { time (hour) }\end{array}$ & $\begin{array}{l}\text { vigor } \\
\text { index }\end{array}$ & $\begin{array}{c}\text { plant height } \\
\left(\mathrm{cm} / \text { plant }^{-}\right)\end{array}$ & $\begin{array}{c}\text { leaves } \\
\text { number/ } \\
\text { plant }\end{array}$ & $\begin{array}{c}\text { fresh } \\
\text { weight } \\
\text { (g) }\end{array}$ & \begin{tabular}{|c|} 
dry \\
weight \\
$(\mathrm{g})$
\end{tabular} \\
\hline $\mathbf{T}_{1} \mathbf{P}_{1}$ & $87.50^{b}$ & $6.41^{\mathrm{ab}}$ & $43.33^{c}$ & $51.00^{\mathrm{de}}$ & $282.80^{\mathrm{e}}$ & $20.20^{c}$ & $8.20^{\mathrm{ab}}$ & $1.89^{\mathrm{a}}$ & $0.70^{\mathrm{a}}$ \\
\hline $\mathbf{T}_{1} \mathbf{P}_{2}$ & $83.33^{c}$ & $6.33^{\mathrm{abc}}$ & $48.80^{\mathrm{d}}$ & $53.12^{\mathrm{e}}$ & $345.60^{c}$ & $21.60^{b c}$ & $7.80^{\mathrm{bc}}$ & $1.84^{\mathrm{a}}$ & $0.64^{\mathrm{a}}$ \\
\hline $\mathbf{T}_{2} \mathbf{P}_{1}$ & $58.66^{\mathrm{f}}$ & $4.16^{\mathrm{d}}$ & $63.18^{\mathrm{e}}$ & $64.19^{f}$ & $148.80^{\mathrm{i}}$ & $18.60^{\mathrm{c}}$ & $8.40^{\mathrm{ab}}$ & $1.84^{\mathrm{a}}$ & $0.56^{\mathrm{a}}$ \\
\hline $\mathbf{T}_{2} \mathbf{P}_{2}$ & $83.33^{c}$ & $6.00^{\mathrm{bc}}$ & $48.95^{\mathrm{d}}$ & $46.67^{\mathrm{bc}}$ & $240.00^{\mathrm{g}}$ & $20.00^{\mathrm{c}}$ & $7.00^{\mathrm{cd}}$ & $2.28^{\mathrm{a}}$ & $0.41^{\mathrm{a}}$ \\
\hline $\mathbf{T}_{3} \mathbf{P}_{1}$ & $91.66^{\mathrm{a}}$ & $7.25^{\mathrm{a}}$ & $25.71^{\mathrm{a}}$ & $33.00^{\mathrm{a}}$ & $520.80^{\mathrm{a}}$ & $25.13^{\mathrm{a}}$ & $8.20^{\mathrm{ab}}$ & $3.66^{\mathrm{a}}$ & $0.70^{\mathrm{a}}$ \\
\hline $\mathbf{T}_{3} \mathbf{P}_{2}$ & $87.50^{\mathrm{b}}$ & $6.58^{\mathrm{ab}}$ & $37.60^{\mathrm{b}}$ & $44.57^{\mathrm{b}}$ & $377.60^{b}$ & $23.60^{\mathrm{ab}}$ & $8.80^{\mathrm{a}}$ & $4.00^{\mathrm{a}}$ & $0.71^{\mathrm{a}}$ \\
\hline $\mathbf{T}_{4} \mathbf{P}_{1}$ & $83.33^{c}$ & $6.16^{\mathrm{abc}}$ & $43.20^{\mathrm{c}}$ & $49.71^{\mathrm{cd}}$ & $266.00^{f}$ & $19.00^{c}$ & $7.20^{\mathrm{cd}}$ & $2.70^{\mathrm{a}}$ & $0.50^{\mathrm{a}}$ \\
\hline $\mathbf{T}_{4} \mathbf{P}_{2}$ & $66.66^{\mathrm{d}}$ & $5.16^{\mathrm{cd}}$ & $42.50^{c}$ & $54.25^{\mathrm{e}}$ & $288.40^{\mathrm{d}}$ & $20.60^{b c}$ & $7.80^{\mathrm{bc}}$ & $2.32^{\mathrm{a}}$ & $0.49^{\mathrm{a}}$ \\
\hline Control & $62.50^{\mathrm{e}}$ & $4.58^{\mathrm{d}}$ & $38.60^{\mathrm{b}}$ & $45.33^{\mathrm{b}}$ & $188.00^{\mathrm{h}}$ & $18.80^{\mathrm{c}}$ & $6.80^{\mathrm{d}}$ & $2.34^{\mathrm{a}}$ & $0.46^{\mathrm{a}}$ \\
\hline $\mathbf{T}$ & $*$ & $*$ & $*$ & $*$ & $*$ & $*$ & $\mathrm{Ns}$ & Ns & $\mathrm{Ns}$ \\
\hline $\mathbf{P}$ & Ns & Ns & Ns & Ns & $*$ & Ns & Ns & Ns & Ns \\
\hline $\mathbf{T} * \mathbf{P}$ & $*$ & Ns & $*$ & $*$ & $*$ & $*$ & $*$ & $\mathrm{Ns}$ & Ns \\
\hline LSD & 2.47 & 1.23 & 2.14 & 3.14 & 2.64 & 3.48 & 0.91 & 2.59 & 0.84 \\
\hline
\end{tabular}

The exposure time: $\mathrm{T}_{1}=45 \mathrm{~s}, \mathrm{~T}_{2}=65 \mathrm{~s}, \mathrm{~T}_{3}=85 \mathrm{~s}$, and $\mathrm{T}_{4}=105 \mathrm{~s}$. Power density: $\mathrm{P}_{1}=4 \mathrm{~mW} / \mathrm{cm}^{2}$, and $\mathrm{P}_{2}=2 \mathrm{~mW} / \mathrm{cm}^{2}$. Means of treatments were compared using the least significant difference (LSD) at $\mathrm{p} \leq 0.01$. Mean values with the same letters in the same column are statistically equal (Fisher's, $\mathrm{a}=0.01$ )

A similar trend was also observed in the mean emergence time as shown in Table 3. The seeds irradiated with $4 \mathrm{~mW} / \mathrm{cm}^{2}$ laser intensity for $65 \mathrm{~s}$ needed $64.19 \mathrm{~h}$ as the average emergence time, whereas those irradiated for $85 \mathrm{~s}$ required only $33 \mathrm{~h}$, showing a significant difference in the respective emergence times. The emergence speed was observed to be $25.7 \mathrm{~h}$ for seeds exposed to $4 \mathrm{~mW} / \mathrm{cm}^{2}$ laser intensity for $85 \mathrm{~s}$, showing a considerable increase compared to seeds irradiated for $85 \mathrm{~s}$ at a laser intensity of $2 \mathrm{~mW} / \mathrm{cm}^{2}(37.6 \mathrm{~h})$ and un-irradiated treatment group $(38.6 \mathrm{~h})$. This reduction in emergence speed for the seeds exposed to laser treatment $\left(\mathrm{T}_{3} \mathrm{P}_{2}\right.$ and $\left.\mathrm{T}_{3} \mathrm{P}_{1}\right)$ was significant at $(\mathrm{p}<0.01)$ when compared to the control seeds. There was also a linear improvement in the seedling vigor index by 520 in seeds treated with a laser power intensity of $4 \mathrm{~mW} / \mathrm{cm}^{2}$ for $85 \mathrm{~s}$ compared to the other treatments. The highest emergence index of 7.25 was recorded for $85 \mathrm{~s}$ of $4 \mathrm{~mW} / \mathrm{cm}^{2}(\mathrm{P}<0.01)$, which was statistically significant in comparison to the control (4.58).

The maximum plant height, fresh and dry weights of seedling were observed in seeds treated with laser for $85 \mathrm{~s}$. The plant height and the number of leaves were increased by a single exposure to laser for $85 \mathrm{~s}(\mathrm{p}<0.01)$ compared to the control set. Laser irradiation for $85 \mathrm{~s}$ at $4 \mathrm{~mW} / \mathrm{cm}^{2}$ significantly increased the plant height $(25.13 \mathrm{~cm})$ for the seedlings from the control seeds $(18.8 \mathrm{~cm})$. The laser treatments also significantly affected the number of leaves per maize plant as shown in Table 2. Increases in the number of leaves per plant for both power densities were observed. The best results (8.8 leaves/plant) were exhibited by seeds irradiated with $2 \mathrm{~mW} / \mathrm{cm}^{2}$ laser intensity for $85 \mathrm{~s}$, followed by those irradiated with $4 \mathrm{~mW} / \mathrm{cm}^{2}$ laser intensity for $85 \mathrm{~s}$ (8.4 leaves/plant). The minimum number of leaves per plant (6.8) was obtained in the un-irradiated control. There was no statistically significant difference between the observed effects of treatments of the fresh and dry weights of the maize seeds (Table 2). 
Table 3. Flowering and seed quality components after seed pre-treatment with blue laser

\begin{tabular}{|c|c|c|c|c|c|c|}
\hline Treatments & $\begin{array}{c}\text { Protein content } \\
(\%)\end{array}$ & $\begin{array}{c}\text { Oil content } \\
(\%)\end{array}$ & $\begin{array}{c}\text { Starch content } \\
(\%)\end{array}$ & \begin{tabular}{|c|} 
Stem diameter \\
$(\mathrm{cm})$
\end{tabular} & $\begin{array}{c}\text { Days to Anthesis } \\
\text { (day) }\end{array}$ & $\begin{array}{c}\text { Days to Silking } \\
\text { (day) }\end{array}$ \\
\hline $\mathbf{T}_{1} \mathbf{P}_{1}$ & $16.30^{\mathrm{ab}}$ & $3.08^{c}$ & $68.78^{\mathrm{cd}}$ & $2.30^{\mathrm{bc}}$ & $60.40^{\mathrm{b}}$ & $61.50^{\mathrm{a}}$ \\
\hline $\mathbf{T}_{1} \mathbf{P}_{2}$ & $14.60^{\mathrm{bc}}$ & $6.22^{\mathrm{a}}$ & $71.25^{\mathrm{b}}$ & $1.90^{\mathrm{c}}$ & $59.33^{\mathrm{b}}$ & $63.90^{\mathrm{a}}$ \\
\hline $\mathbf{T}_{2} \mathbf{P}_{1}$ & $16.67^{\mathrm{ab}}$ & $3.95^{\mathrm{bc}}$ & $66.30^{\mathrm{cd}}$ & $2.20^{\mathrm{bc}}$ & $58.92^{\mathrm{ab}}$ & $63.30^{\mathrm{a}}$ \\
\hline $\mathbf{T}_{2} \mathbf{P}_{2}$ & $16.70^{\mathrm{ab}}$ & $6.18^{\mathrm{a}}$ & $69.40^{c}$ & $1.90^{\mathrm{c}}$ & $59.13^{\mathrm{ab}}$ & $62.70^{\mathrm{a}}$ \\
\hline $\mathbf{T}_{3} \mathbf{P}_{1}$ & $18.00^{\mathrm{a}}$ & $6.33^{\mathrm{a}}$ & $76.83^{\mathrm{a}}$ & $3.50^{\mathrm{a}}$ & $56.20^{\mathrm{a}}$ & $62.25^{\mathrm{a}}$ \\
\hline $\mathbf{T}_{3} \mathbf{P}_{2}$ & $18.20^{\mathrm{a}}$ & $6.22^{\mathrm{a}}$ & $73.11^{\mathrm{a}}$ & $2.80^{\mathrm{abc}}$ & $58.72^{\mathrm{ab}}$ & $64.00^{\mathrm{a}}$ \\
\hline $\mathbf{T}_{4} \mathbf{P}_{1}$ & $13.70^{c}$ & $3.81^{\mathrm{bc}}$ & $71.76^{\mathrm{b}}$ & $2.30^{\mathrm{bc}}$ & $61.40^{\mathrm{b}}$ & $64.10^{\mathrm{a}}$ \\
\hline $\mathbf{T}_{4} \mathbf{P}_{2}$ & $14.80^{\mathrm{bc}}$ & $4.27^{\mathrm{bc}}$ & $63.82^{\mathrm{e}}$ & $2.60^{\mathrm{abc}}$ & $60.83^{b}$ & $65.40^{\mathrm{a}}$ \\
\hline Control & $16.80^{\mathrm{ab}}$ & $4.37^{\mathrm{b}}$ & $70.12^{\mathrm{bc}}$ & $2.90^{\mathrm{ab}}$ & $61.40^{\mathrm{b}}$ & $63.00^{\mathrm{a}}$ \\
\hline $\mathbf{T}$ & $*$ & $*$ & $*$ & Ns & $*$ & Ns \\
\hline $\mathbf{P}$ & Ns & $*$ & Ns & Ns & Ns & Ns \\
\hline $\mathbf{T} * \mathbf{P}$ & Ns & $*$ & $*$ & $*$ & $*$ & Ns \\
\hline LSD & 2.47 & 1.23 & 1.76 & 0.91 & 2.97 & 3.60 \\
\hline
\end{tabular}

The exposure time: $T_{1}=45 \mathrm{~s}, T_{2}=65 \mathrm{~s}, T_{3}=85 \mathrm{~s}$, and $T_{4}=105 \mathrm{~s}$. Power density: $P_{1}=4 \mathrm{~mW} / \mathrm{cm}^{2}$, and $\mathrm{P}_{2}=2 \mathrm{~mW} / \mathrm{cm}^{2}$. Means of treatments were compared using the least significant difference (LSD) at $\mathrm{p} \leq 0.01$. Mean values with the same letters in the same column are statistically equal (Fisher's, $\mathrm{a}=0.01$ )

Table 3 also presents the effect of laser exposure on the oil content of the seeds. The laser-treated seeds and the control seeds presented a comparable level of oil content. As shown in Table 3, there were significant differences in the oil content of the seed. Generally, the oil contents of the seeds were increased by exposure to laser for different exposure times, where seeds exposed for $85 \mathrm{~s}$ to $4 \mathrm{~mW} / \mathrm{cm}^{2}$ laser intensity showed higher oil content $(6.33 \%)$, followed by those exposed to $2 \mathrm{~mW} / \mathrm{cm}^{2}$ laser intensity $(6.22 \%)$. The control seeds showed the lowest oil content (4.37\%). Highest levels of total protein content and starch content were recorded in seeds exposed to laser for $85 \mathrm{~s}$ compared to the control $(\mathrm{p}<0.01)$. The exposure of maize seeds to laser at different exposure times had a significant influence on the protein content of the seeds (Table 3). An increase in the exposure time to laser was generally found to increase the protein content of the seeds, with the highest protein content of $18.2 \%$ being observed in seeds exposed to $2 \mathrm{~mW} / \mathrm{cm}^{2}$ laser power for $85 \mathrm{~s}$, followed by $18 \%$ for seeds exposed to $4 \mathrm{mw} / \mathrm{cm}^{2}$ laser power for $85 \mathrm{~s}$. The control seeds had a protein content of $16.8 \%$. The protein content increased gradually, and the maximum activities were noted in seedlings derived from $85 \mathrm{~s}$ laser irradiated seeds, whereas the starch content showed maximum activity at $85 \mathrm{~s}$ which was found to be significant $(\mathrm{p}<0.01)$ compared to the control group. The different energy densities of laser irradiation also increased the stem diameter during the harvest stage. Pre-sowing exposure to $4 \mathrm{~mW} / \mathrm{cm}^{2}$ laser power for $85 \mathrm{~s}$ was observed to significantly increase the stem diameter of the plants $(3.5 \mathrm{~cm})$ compared to the stems of the control seeds $(2.9 \mathrm{~cm})$.

Regarding the days to silking, Table 3 shows a marked difference in the days to silking of the maize plants exposed to laser for different exposure times. However, there was no statistically significant difference between the observed effects. The shortest period (61.5 day) was observed in plant seeds exposed to $4 \mathrm{~mW} / \mathrm{cm}^{2}$ blue laser for $45 \mathrm{~s} \mathrm{compared}$ to 65.4 day of the control group. There were also significant differences in the Days to Anthesis as presented in Table 3. In general, using different exposure times led to an 
increase in the Days to Anthesis. For the blue laser, $85 \mathrm{~s}$ of exposure at $4 \mathrm{~mW} / \mathrm{cm}^{2}$ has a shorter period to Anthesis ( 56.2 day), followed by seeds irradiated with a power density of $2 \mathrm{~mW} / \mathrm{cm}^{2}$ (58.72 day). The control group had the longest period to Anthesis (61.4 day).

\section{Discussion}

Seed germination is a crucial stage in plant development and can be considered as a determinant for plant productivity. Physiological and biochemical changes followed by morphological changes during germination are strongly related to seedling survival rate and vegetative growth which consequently affect yield and quality. Seed stimulates the embryo to produce phytohormones mainly gibberellic acid (GA) which can diffuse to aleurone layer and initiate a signaling cascade resulting in the synthesis of a-amylases and other hydrolytic enzymes.

Phytochromes are involved in the sensing of the light environment by seeds, and the control of germination by red and far-red light was one of earliest phytochrome-mediated responses described Phytochromes can affect the growth capacity of the embryo and/or the constraint imposed by seed tissues around it. Much evidence exists for the role of phytochromes in promoting the synthesis of gibberellins (GAs), which are important stimulants for germination (García-Martinez and Gil, 2001; Hilhorst et al., 2018; Ribalta et al., 2019). Phytochromes also play a role in regulating the sensitivity to GAs (Mishra and Khurana, 2017). Recently, phytochromes have also been shown to be involved in the degradation of abscisic acid, the major plant hormone that maintains dormancy (Miransari and Smith, 2014).

Hernandez et al. $(2010,2011)$ presented a detailed review of the use of laser treatment for plant stimulation. The review suggested that laser light can be used in agriculture for seeds bio-stimulation based on the additive interaction between the laser beam (polarized and monochromatic) and the photoreceptors that absorb it. This interaction activates several biological processes in the exposed seeds. However, the level of effect of laser treatment is a function of the laser wavelength, the output power, and the period of exposure.

According to several reports, various laser output powers have been investigated (Govil et al., 1991; Jia and Duan, 2013) to $5 \mathrm{~mW}$ (Hernandez et al., 2010). Different periods of exposure have also been studied, ranging from $30 \mathrm{~s}$ (Hernández and Michtchenko, 2011) to $120 \mathrm{~min}$ (Khalifa and El Ghandoor, 2011). In the present study, the highest emergence rate was presented by seeds exposed to $4 \mathrm{~mW} / \mathrm{cm}^{2}$ laser intensity for $85 \mathrm{~s}$ which is comparable to earlier reports by Ćwintal et al. (2010). According to several authors, laser treatment can also cause some levels of damage to plant cells and tissues (Jia and Duan, 2013). As per Salyaev et al. (2007) and Hernandez et al. (2010), there are two specific responses which can be induced upon exposure of cells to laser light: (i) a rapid stress effect which increases the level of lipid peroxidation products generation, and (ii) series of secondary reactions due to the adaptive metabolic changes which can elicit some morphogenetic processes. The present results agreed with previous findings by Taie et al. (2014) who reported the maximum germination percentage of some Merremia sp. upon exposure to laser light. In a study on Stevia seeds, Goettemoeller and Ching (1999) reported that the two weeks-delay and the low seed germination percentage observed in the control set could be attributed to the importance of light to the germination of Stevia seeds (light-requiring seeds) as the exposed seeds showed better germination 
percentage compared to the control. All light-requiring seeds have also been earlier reported to show dormancy (Taiz and Zeiger, 2011), while the importance of light to seed germination and plant growth has been reported (Hernandez et al., 2009).

However, upon completion of germination, Jala (2011) recorded the highest germination percentage in seeds treated with laser light. The present results on germination show deviation from Jala (2011) but in line with Colbach et al. (2002) on Alopecurus myosuroides and Ambika (2007) on Chromolaena odorata seeds. Horizontal and vertical expansion of shoot, particularly leaves, is a genetically-controlled developmental process (Tsukaya, 1998) and irradiation with blue light seems to cause imbalance in the expression of the concerned genes, leading to inhibition of leaf expansion. Furthermore, the improved rate of seed germination could be attributed to the matter and energy transfer processes involved in the germination and growth of seeds (Abu-Elsaoud et al., 2013). For instance, different intensities of laser treatment have been reported to induce the germination of wheat and maize seeds, as well as some vegetables (Asghar et al., 2016). The spectral influence of laser treatment on seed germination has also been investigated by Chen et al. (2005) in which laser light was reported to induce changes in the normal plant functions, and elicited rapid cell division, resulting in a rapid rate of initial growth and development. Therefore, the observed positive effects of laser light treatment on the seed germination parameters in the present study could be attributed to an improved rate of laser-induced cell division. Some reports have also reported that laser treatment is a physical process involves the absorption and storage of radiant energy by the cells and tissues of plants. This is also applicable to seeds as they first absorb the radiation energy before its subsequent transformation into chemical energy for subsequent use (El-Naggar et al., 2012; Hedimbi and Singh, 2012; AlSalhi et al., 2018).

According to Hernandez et al. (2010), the pre-sowing exposure of various seeds (like rice, maize, tomato, radish, peas, cucumber, lettuce, onion, etc.) to laser has a significant influence on their germination parameters. The seeds of vegetables have been reported as the most sensitive seeds to laser stimulation compared to cereals (Gładyszewska, 2006; Hernandez et al., 2015). Laser radiation of different exposure times (45, 65, 85, and $105 \mathrm{~s})$ as used in the present study showed different effects on maize plants. Statistical analysis of this work reveals that plant height, number of leaves and stem diameter increased by laser treatments and this may reflect the effect of laser on cell division of shoot taps of the exposed shoots. This effect continued in the cell division of all parts of the plant at both vegetative and flowering stages. Our results reveal that the exposure to blue laser rays for $85 \mathrm{~s}$ and $4 \mathrm{~mW} / \mathrm{cm}^{2}$ laser intensity had the most pronounced effect in increasing the growth criteria for maize plant and decreased emergence time. A similar effect was also noticed by Podleśna et al. (2015). These results agree with Chen et al. (2005) who showed changes in the protein functional activities. There were also increases in the physiological and biochemical characteristics of the seedlings after exposure to laser (Chen et al., 2005; Qiu et al., 2013). The exposure time to laser radiation is very important to produce stimulation effects and these agree with the report of Rimal et al. (2014).

From the in-vitro growth data, it was observed that different exposure times to blue laser increased the germination and shoot multiplication rates of maize plants. This was supported by the reports of Hwida et al. (2012) on Balanites aegyptiaca and Cotoneaster horizontalis and Dănăilă et al. (2011) on Petunia hybrid and Dianthus caryophyllus plants. According to earlier reports on Balanites aegyptiaca, the maximum number of shootlets per explant increases with laser treatments (Lobna et al., 2014; Rania et al., 2015). The maize seeds exposed to blue laser for $85 \mathrm{~s}$ had the longest plants compared to the control. 
These results showed the same trend with the reports of Ali et al. (2014), Lobna et al. (2014), and Kouchebagh et al. (2014b). The laser-induced cell elongation has been reported to increase the level of gibberellic acid which results in increased cell vacuoles (Mahmoud and Ibrahem, 2000). Regarding the number of leaves, the seeds exposed to blue laser for $85 \mathrm{~s}$ has plants with the highest number of leaves per plant compared to the control. This observation agreed with the reports of earlier studies (MacLeod and Millar, 1962; Kamiya and Martinez, 1999; Aguilar et al., 2015).

Osman et al. (2009) and Aguilar et al. (2015) suggested that laser radiation could induce faster rates of enzymatic activities within the cells of the exposed seeds. This could also be due to the endogenous GA content and its role in cell growth. It is believed that GA can induce cell growth by inducing enzymes that reduce the integrity of the cell wall (MacLeod and Millar, 1962). Seeds exposed to blue laser for 85 s produced plants with the longest stem diameter and dry and fresh weights compared to the control. Plant growth is generally controlled by several factors, such as enzymes and hormones like gibberellic acid $\left(\mathrm{GA}_{3}\right)$ and cytokinin. Kamiya and Martinez (1999) observed that exposure to laser plays a significant role in $\mathrm{GA}_{3}$ formation and endogenous level of $\mathrm{GA}_{1}$. The resulting increase in $\mathrm{GA}_{3}$ response manifests in better cell growth, reduced cell wall integrity, proteolytic enzymes production, increased auxin content, and increased sugar concentration; can also increase the osmotic pressure of the cell sap. The physical manifestations of the increased cell elongation due to laser radiation are increased plant height and number of branches, as well as increased number of flowers (Ali et al., 2014; Rania et al., 2015). Exposure to laser can also increase the nitrogen content and result in increased protein content. This is necessary for the development of plant organs (such as the branches and umbels) (Osman et al., 2009). The study by Mahmoud and Ibrahem (2000) showed that laser irradiation can increase cell number, nucleic acids, and phospholipids membranes. It can also increase the potassium and phosphorus contents, thereby leading to the elongation of laser-irradiated cells.

However, further details are needed on the effects of different laser irradiation as they remain inexplicable (Samuilov and Garifullina, 2007). Coherent laser light beams excite electrons and promote the biophoton and entropy emission, thereby triggering an increase in the internal energy of the exposed material. The transient action of laser irradiation has also been implicated in the stimulation of various functional activities and higher plants' resistance to biotic disease (Rassam, 2010; Podleśny et al., 2012; Srećković et al., 2014; Tang et al., 2019). The role of laser technology in the agricultural sector is being evaluated from its bio-stimulatory role. Despite the reported positive influences of laser irradiation (visible to near IR), its light-regulated mechanism and role in plants are yet to be understood (Aguilar et al., 2015). Laser irradiation is emerging as a novel agricultural practice owing to its positive role in seed germination, seeds biochemical composition, enzyme activities, plant growth, seed quality, stress resistance, fruit size, and yield characteristics. Corn seeds stained with methylene blue were treated by Hernández et al. (2011) using a laser diode, a wavelength of $655 \mathrm{~nm}$ with $27.4 \mathrm{~mW}$ of power and $5 \mathrm{~min}$ of exposure. In these seeds, the number of seeds infected by Fusarium spp. was reduced, suggesting the possibility of using laser irradiation as a means of disease control in maize seeds, thereby improving the quality of seeds and the final product derived from plants emerging from such seeds. 


\section{Conclusion}

In the present study, the pre-sowing exposure of maize seeds to blue laser light at $4 \mathrm{~mW} / \mathrm{cm}^{2}$ laser intensity and $85 \mathrm{~s}$ exposure time significantly improved the seedling emergence rate and improved the seed emergence uniformity. Significant modification was also observed in the stages of plant growth. Such use of the laser is technically feasible and could be one of the solutions to increase seed emergence, seedling growth and establishment of more efficient maize seeds. However, future study is needed to understand the mechanism underlying phytohormones by the optimum blue laser pretreatment.

Acknowledgements. This research was supported by the Ministry of Education Malaysia (FRGS/1/2018/WAB05/UKM/02/2) and UKM research grant (DIP-2019-001).

\section{REFERENCES}

[1] AACC. (2000): American Association of Cereal Chemists. International approved methods of analysis (10th ed.). - AACC International St Paul MN U.S.A.

[2] Abu-Elsaoud, A. M., Tuleukhanov, S. T. (2013): Can He-Ne laser induce changes in oxidative stress and antioxidant activities of wheat cultivars from Kazakhstan and Egypt. - Science international 1(3): 39-50.

[3] Aguilar, C. H., Pacheco, F. A. D., Orea, A. C., Tsonchev, R. I. (2015): Thermal effects of laser irradiation on maize seeds. - International Agrophysics 29(2): 147-156.

[4] Aladjadjiyan, A. (2012): Physical factors for plant growth stimulation improve food quality. - Food production-approaches, challenges and tasks, doi: 10.5772/32039.

[5] Ali, S. M., Sharbat, L. M. M., Bedour, H. A. L., Sayed, A. M. (2014): Effect of drought stress and helium neon (He-Ne) laser rays on growth, oil yield and fatty acids content in caster bean (Ricinus communis L.). - Agriculture Forestry and Fisheries 3(3): 203-208.

[6] AlSalhi, M. S., Tashish, W., Al-Osaif, S. S., Atif, M. (2018): Effects of He-Ne laser and argon laser irradiation on growth, germination, and physico-biochemical characteristics of wheat seeds (Triticumaestivum L.). - Laser Physics 29(1): 015602.

[7] Álvarez, A., Ramírez, R., Chávez, L., Camejo, Y. (2011): Effect of the treatment of seeds with radiation laser of fall promotes in a hybrid of tomato (Solanum lycopersicum L.). Revista Granma Ciencia 15(2): 1-9.

[8] Ambika, S. R. (2007): Effect of light quality and intensity on emergence, growth and reproduction in Chromolaena odorata. - In: International Workshop on Biological Control and Management of Chromolaena odorata and Mikania micrantha, p.14.

[9] Asghar, T., Jamil, Y., Iqbal, M., Abbas, M. (2016): Laser light and magnetic field stimulation effect on biochemical, enzymes activities and chlorophyll contents in soybean seeds and seedlings during early growth stages. - Journal of Photochemistry and Photobiology B: Biology 165: 283-290.

[10] Ashrafijou, M., Noori, S. S., Darbandi, A. I., Saghafi, S. (2010): Effect of salinity and radiation on proline accumulation in seeds of canola (Brassica napus L.). - Plant, Soil and Environment 56(7): 312-317.

[11] Association of Official Seed Analysts. (1978): Rules for testing seeds. - The Association.

[12] Atif, M. J., Amin, B., Ghani, M. I., Ali, M., Cheng, Z. (2020): Variation in morphological and quality parameters in garlic (Allium sativum L.) bulb influenced by different photoperiod, temperature, sowing and harvesting time. - Plants 9(2): 155.

[13] Aziz, N. I. H. A., Hanafiah, M. M., Halim, N. H., Fidri, P. A. S. (2020a): Phytoremediation of TSS, $\mathrm{NH}_{3}-\mathrm{N}$ and COD from sewage wastewater by Lemna minor L., Salvinia minima, Ipomea aquatica and Centella asiatica. - Applied Sciences 10(16): 5397. 
[14] Aziz, N. I. H. A., Hanafiah, M. M., Gheewala, S. H., Ismail, H. (2020b). Bioenergy for a Cleaner Future: A Case Study of Sustainable Biogas Supply Chain in the Malaysian Energy Sector. - Sustainability 12: 3213.

[15] Bessis, M., Gires, F., Mayer, G., Nomarski, G. (1962): Irradiation des organites cellulaires á l'aide d'un laser á rubis. - CR Acad. Sci 255: 1010-1012.

[16] Bouly, J. P., Schleicher, E., Dionisio-Sese, M., Vandenbussche, F., Van Der Straeten, D., Bakrim, N, Ahmad, M. (2007): Cryptochrome blue light photoreceptors are activated through interconversion of flavin redox states. - Journal of Biological Chemistry 282(13): 9383-9391.

[17] Chen, Y. P., Liu, Y. J., Wang, X. L., Ren, Z. Y., Yue, M. (2005): Effect of microwave and $\mathrm{He}-\mathrm{Ne}$ laser on enzyme activity and biophoton emission of isatis indigotica fort. - Journal of Integrative Plant Biology 47(7): 849-855.

[18] Colbach, N., Dür, C., Chauvel, B., Richard, G. (2002): Effect of environmental conditions on Alopecurus myosuroides germination. II. Effect of moisture conditions and storage length. - Weed Research 42(3): 222-230.

[19] Ćwintal, M., Dziwulska-Hunek, A., Wilczek, M. (2010): Laser stimulation effect of seeds on quality of alfalfa. - Int. Agrophys 24(1): 15-19.

[20] Dănăilă-Guidea, S. I., Niculiţă, P., Esofina, R., Mona, P., Marian, R., Floarea, B., Mihaela, G. (2011): The influence of modulated red laser light on seedlings of some annual ornamental species (Dianthus caryophyllus and Petunia hybrida). - Romanian Biotechnological Letters 16(6 Supplement): 34-39.

[21] El-Naggar, A. Y., Shetaia, Y. M., Youssef, K. A., Ismail, N. A. (2012): Stimulation of the hydrocarbon compounds degrading Saccharomyces rosinii by low power laser radiation. Der Pharma Chemica 4(4): 1424-1434.

[22] Fadillah, M. N., Marlia, M. H. (2016): Malaysian water footprint accounts: Blue and green water footprint of rice cultivation and the impact of water consumption in Malaysia. - In: AIP Publishing LLC, AIP Conference Proceedings 1784(1): 060025.

[23] FAO, IFAD, IMF, OECD, UNCTAD, WFP (2011): Price volatility in food and agricultural markets: Policy responses. - FAO: Roma, Italy.

[24] Ferdosizadeh, L., Sadat-Noori, S. A., Zare, A., Syghafi, S. (2013): Assessment of diode laser pretreatments on germination and yield of wheat (Triticum aestivum L.) under salinity stress. - World Journal of Agricultural Research 1(1): 5-9.

[25] Field, C. B., Barros, V., Stocker, T. F., Dahe, Q. (eds.) (2012): Managing the risks of extreme events and disasters to advance climate change adaptation: special report of the intergovernmental panel on climate change. - Cambridge University Press.

[26] Foley, J. A. (2011): Can we feed the world sustain the planet? - Scientific American 305(5): 60-65.

[27] García-Martinez, J. L., Gil, J. (2001): Light Regulation of Gibberellin Biosynthesis and Mode of Action. - Journal Plant Growth Regulation 20(4): 354-368.

[28] Gładyszewska, B. (2006): Pre-sowing laser biostimulation of cereal grains. - Technology Science 6: 33-38.

[29] Goettoeller, J., Ching, A. (1999): Seed germination in Stevia rebaudiana. - In: Jadick, J. (ed.) Perspective on new crops and new uses. ASHS Press, Alexandria, VA.

[30] Govil, S. R., Agrawal, D. C., Rai, K. P., Thakur, S. N. (1991): Physiological responses of Vigna radiata $\mathrm{L}$. to nitrogen and argon+ laser irradiation-Short Communication. - Indian Journal of Plant Physiology 34(1): 72-76.

[31] Hanafiah, M. M., Ghazali, N. F., Harun, S. N., Abdulaali, H. S., AbdulHasan, M. J., Kamarudin, M. K. A. (2019): Assessing water scarcity in Malaysia: a case study of rice production. - Desalination and Water Treatment 149: 274-287.

[32] Harun, S. N., Hanafiah, M. M. (2018): Estimating the country-level water consumption footprint of selected crop production. - Applied Ecology and Environmental Research 16(5): 5381-5403. 
[33] Hasan, M., Hanafiah, M. M., Aeyad Taha, Z., AlHilfy, I. H., Said, M. N. M. (2020): Laser Irradiation Effects at Different Wavelengths on Phenology and Yield Components of Pretreated Maize Seed. - Applied Sciences 10(3): 1189.

[34] He, J., Qin, L., Chong, E. L., Choong, T. W., Lee, S. K. (2017): Plant growth and photosynthetic characteristics of Mesembryanthemum crystallinum grown aeroponically under different blue-and red-LEDs. - Frontiers in plant science 8: 361.

[35] Hedimbi, M., Singh, S. (2012): Laser induced fluorescence study on the growth of maize plants. - Nat. Sci. 4(06): 395.

[36] Hernandez, A. C., Dominguez-Pacheco, A., Cruz-Orea, A., Ivanov, R., Carballo-Carballo, A., Zepeda-Bautista, R., Galindo Soria, L. (2009): Laser irradiation effects on field performance of maize seed genotypes. - International Agrophysics 23: 327-332.

[37] Hernandez, A. C., Dominguez, P. A., Cruz, O. A., Ivanov, R., Carballo, C. A., Zepeda, B. R. (2010): Laser in agriculture. - International Agrophysics 24(4): 407-422.

[38] Hernández, M., Michtchenko, A. (2011): Stimulation of three Biological Systems Using Low Level Laser Radiation. - RISCE Revista Internacional de Sistemas Computacionales y Electrónicos 83(3): 30-33.

[39] Hernandez, A. C., Dominguez-Pacheco, A., Cruz-Orea, A. (2015): Thermal changes of maize seed by laser irradiation. - International Journal of Thermophysics 36(9): 24012409.

[40] Hilhorst, H. W. (2018): Definitions and hypotheses of seed dormancy. - Annual Plant Reviews online, pp. 50-71.

[41] Hoseini, M., Feqenabi, F., Tajbakhsh, M., Babazadeh-Igdir, H. (2013): Introduction of seed treatment techniques (seed priming). - International Journal of Biosciences (IJB) 3(5): 112 .

[42] Hwida, M. F., Metwally, S. A., Lobna, S. T. (2012): In vitro growth behavior and leaf anatomical structure of Balanites aegyptiaca and Cotoneoster horizontalis affected by different types of laser radiation. - Journal of Applied Sciences Research 8(4): 2386-2396.

[43] Jala, A. (2011): Effects of different light treatments on the germination of Nepenthes mirabilis. - International Transaction Journal of Engineering, Management, \& Applied Sciences \& Technologies 2(1): 083-091.

[44] Jamil, Y., Perveen, R., Ashraf, M., Ali, Q., Iqbal, M., Ahmad, M. R. (2013): He-Ne laserinduced changes in germination, thermodynamic parameters, internal energy, enzyme activities and physiological attributes of wheat during germination and early growth. Laser Physics Letters 10(4): 045606.

[45] Jia, Z., Duan, J. (2013): Protecting effect of He-Ne laser on winter wheat from UV-B radiation damage by analyzing proteomic changes in leaves. - Advances in Bioscience and Biotechnology 4(8): 823-829.

[46] Joshi, S., Joshi, G., Agrawal, H. (2012): Study on the effect of laser irradiation on wheat (Triticum aestivum L.) variety PBW-373 seeds on zinc uptake by wheat plants. - Journal of Radioanalytical and Nuclear Chemistry 294(3): 391-394.

[47] Kamiya, Y., García-Martínez, J. L. (1999): Regulation of gibberellin biosynthesis by light. - Current opinion in plant biology 2(5): 398-403.

[48] Khalifa, N. S., El Ghandoor, H. (2011): Investigate the effect of Nd-Yag laser beam on soybean (Glycin max) leaves at the protein level. - International Journal of Biology 3(2): 135.

[49] Kouchebagh, S. B., Farahvash, F., Mirshekari, B., Arbat, H. K., Khoei, F. R. (2014a): Seed priming techniques may improve grain and oil yields of sunflower (Helianthus annuus L.). - The Journal of Animal \& Plant Sciences 24(6): 1863-1868.

[50] Kouchebagh, S. B., Farahvash, F., Mirshekari, B., Arbat, H. K., Khoei, F. R. (2014b): Effects of physical treatments on germination and stand establishment of sunflower (Helianthus annuus L. var. Hyson) under laboratory condition. - International Journal of Biosciences 5(12): 1-6. 
[51] Levskaya, A., Weiner, O. D., Lim, W. A., Voigt, C. A. (2009): Spatiotemporal control of cell signalling using a light-switchable protein interaction. - Nature 461(7266): 997-1001.

[52] Lobna, S. T., Hanan, A. A. T., Metwally, S. A., Hwida, M. F. (2014): Effect of laser radiation treatments on in vitro growth behavior, antioxidant activity and chemical constituents of Sequoia sempervirens. - Research Journal of Pharmaceutical Biological and Chemical Science 5(4): 1024-1034.

[53] MacLeod, A. M., Millar, A. S. (1962): Effects of gibberellic acid on barley endosperm. Journal of the Institute of Brewing 68(4): 322-332.

[54] Mahmoud, M. M., Ibrahem, S. E. (2000): Plant physiology. - Fac. of Agric., Ain Sams Univ. pp. 164-85.

[55] Metwally, S. A., Abou-Ellail, M., Abo-Leila, B. H., Aboud, K. A. (2013): Effect of laser radiation on the growth, anatomical and biochemical genetic markers of Celosia argentea plants. - International Journal of Academic Research 5(3): 200-205.

[56] Miransari, M., Smith, D. L. (2014): Plant hormones and seed germination. - Environmental and Experimental Botany 99: 110-121.

[57] Mishra, S., Khurana, J. P. (2017): Emerging roles and new paradigms in signaling mechanisms of plant cryptochromes. - Critical reviews in plant sciences 36(2): 89-115.

[58] Mohssen, N. F., Sharafi, Z. M., Siadat, A. (2010): Study the effect of aging acceleration test on germination and seedling growth of wheat cultivars in controlled conditions (in vitro). - Crop Physiology 2(3): 59-71.

[59] Muhammad-Muaz, A., Marlia, M. H. (2014): Water footprint assessment of oil palm in Malaysia: a preliminary study. - In: American Institute of Physics, AIP Conference Proceedings 1614(1): 803-807.

[60] Nasim, H., Jamil, Y. (2014): Diode lasers: From laboratory to industry. - Optics \& Laser Technology 56: 211-222.

[61] Osman, Y. A., El-Tobgy, K. M., El-Sherbini, E. S. A. (2009): Effect of laser radiation treatments on growth, yield and chemical constituents of fennel and coriander plants. Journal Applied Science Research 5: 244-252.

[62] Perveen, R., Ali, Q., Ashraf, M., Al-Qurainy, F., Jamil, Y., Raza Ahmad, M. (2010): Effects of different doses of low power continuous wave He-Ne laser radiation on some seed thermodynamic and germination parameters, and potential enzymes involved in seed germination of sunflower (Helianthus annuus L.). - Photochemistry and photobiology 86(5): 1050-1055.

[63] Podlesna, A., Gladyszewska, B., Podlesny, J., Zgrajka, W. (2015): Changes in the germination process and growth of pea in effect of laser seed irradiation. - International Agrophysics 29(4): 485-492.

[64] Podleśny, J., Stochmal, A., Podleśna, A., Misiak, L. E. (2012): Effect of laser light treatment on some biochemical and physiological processes in seeds and seedlings of white lupine and faba bean. - Plant Growth Regulation 67(3): 227-233.

[65] Qi, Z., Yue, M., Han, R., Wang, X. L. (2002): The Damage Repair Role of He-Ne Laser on Plants Exposed to Different Intensities of Ultraviolet-B Radiation. - Photochemistry and photobiology 75(6): 680-686.

[66] Qiu, Z., Li, J., Zhang, M., Bi, Z., Li, Z. (2013): He-Ne laser pretreatment protects wheat seedlings against cadmium-induced oxidative stress. - Ecotoxicology and environmental safety 88: 135-141.

[67] Qiu, Z., Yuan, M., He, Y., Li, Y., Zhang, L. (2017): Physiological and transcriptome analysis of He-Ne laser pretreated wheat seedlings in response to drought stress. Scientific reports 7(1): 1-12.

[68] Rania, A. T., Lobna, S. T., Metwally, S. A. (2015): In vitro cultures of jojoba (Simmondsia chinensis L.) affecting by laser irradiation. - Journal of Chemical, Biological and Physical Sciences. 5(4): 3906-3913. 
[69] Rassam, Y. Z. (2010): The Effect of laser light on virulence factors and antibiotic susceptibility of locally isolated Pseudomonas aeruginosa. - Journal of Applied Sciences Research 6(8): 1298-302.

[70] Ribalta, F. M., Pazos-Navarro, M., Edwards, K., Ross, J. J., Croser, J. S., Ochatt, S. J. (2019): Expression patterns of key hormones related to pea (Pisum sativum L.) embryo physiological maturity shift in response to accelerated growth conditions. - Frontiers in plant science 10: 1154 .

[71] Rimal, B., Ranaivoson, R. M., Czarnecka, K. P., Dobrowolski, J. W. (2014): Laser biotechnology for enhanced rooting and shooting of Salix viminalis in hydroponic condition for better adaptation in industrially contaminated land. - International Journal of Environmental Bioremediation \& Biodegradation 2(5): 228-230.

[72] Salyaev, R. K., Dudareva, L. V., Lankevich, S. V., Makarenko, S. P., Sumtsova, V. M., Rudikovskaya, E. G. (2007): Effect of low-intensity laser irradiation on the chemical composition and structure of lipids in wheat tissue culture in doklady. - Biological Sciences 412: 87-88.

[73] Samuilov, F. D., Garifullina, R. L. (2007): Effect of laser irradiation on microviscosity of aqueous medium in imbibing maize seeds as studied with a spin probe method. - Russian Journal of Plant Physiology 54(1): 128.

[74] Śliwka, M. (2014): Assessment of impact of coherent light on resistance of plants growing in unfavourable environmental conditions. - Journal of Ecological Engineering 15(2).

[75] Soliman, A., Harith, M. A. (2009): Effects of Laser Biostimulation on Germination of Acacia farnesiana (L.) Willd. - In: XIII International Conference on Medicinal and Aromatic Plants 854: 41-50.

[76] Srećković, M., Vasić, R., Dukić, M., Jevtić, S., Jovanić, P. (2014): The influence of diode and He-Ne Lasers on corn and wheat seeds. - Journal Agricultural Science and Technology 4: 165-175.

[77] Taie, H. A. A., Taha, L. S., Metwally, S. A., Fathy, H. M. (2014): Effect of laser radiation treatments on in vitro growth behavior, antioxidant activity and chemical constituents of Sequoia sempervirens. - Research Journal of Pharmaceutical, Biological and Chemical Sciences 5(4): 1024-1034.

[78] Taiz, L., Zeiger, E. (2011): A Companion to Plant Physiology in the Fifth Edition, Types of Seed Dormancy and the Roles of Environmental Factors. - Sinauer Associates Inc.

[79] Tang, Z., Yu, J., Xie, J., Lyu, J., Feng, Z., Dawuda, M. M., Hu, L. (2019): Physiological and Growth Response of Pepper (Capsicum annum L.) Seedlings to Supplementary Red/Blue Light Revealed through Transcriptomic Analysis. - Agronomy 9(3): 139.

[80] Truchliñski, J., Koper, R., Starczynowska, R. (2002): Influence of pre-sowing red light radiation and nitragine dressing of chickling vetch seeds on the chemical composition of their yield. - International Agrophysics 16(2): 147-150.

[81] Tsukaya, H. (1998): Genetic evidence for polarities that regulate leaf morphogenesis. Journal of plant research 111(1): 113-119.

[82] Wilczek, M., Koper, R., Cwintal, M., Kornillowicz-Kowalska, T. (2005): Germination capacity and health status of hybrid alfalfa seeds after laser treatment. - International agrophysics 19(3): 257. 